\title{
On the organization of excavation and transportation equipment in the coal-bearing zones at open pit mines
}

\author{
Maxim Tyulenev ${ }^{1 *}$, Sergey Markov ${ }^{1}$, Oleg Litvin ${ }^{1}$, Michal Cehlár ${ }^{2}$, and Yaroslav Litvin ${ }^{3}$ \\ ${ }^{1}$ T.F. Gorbachev Kuzbass State Technical University, Open Pit Mining Department, 650000 \\ Kemerovo, 28 Vesennyaya st., Russian Federation \\ ${ }^{2}$ Technical University in Kosice, Faculty of Mining, Ecology, Process Control and Geotechnologies, \\ Letná 9, 04200 Kosice, Slovak Republic \\ ${ }^{3}$ Branch of JSC «UK Kuzbassrazrezugol» Mokhovsky Open Pit Mine, Mokhovo settlement, \\ Belovsky district, 652661, Kemerovo region, Russia
}

\begin{abstract}
One of the essential issues of the benches' development procedure is the choice of the method of seam development in the complex structure: joint development of rock and coal seams in one complex face or their separate excavation in blocks of 50-100 $\mathrm{m}$ in length. The decision of this question is connected with the mode of mining works, represented by the schedule of stripping and winning works. The choice of one or another method is connected with operative-dispatching control of haul trucks delivery. When rock and coal are mined together in a complex face, overburden haul trucks should be supplied for loading rock and coal haul trucks for coal in turns. It is organizationally difficult to supply haul trucks of different purposes during the shift. It is necessary to proceed from the shift (daily) planning of haul trucks supply for specific faces. In addition, it is necessary to take into account that rock and coal faces are often located on opposite sides of the quarry pit. This article studies the issue of organizing the operation of excavation and loading equipment during the mining of the coal-bearing zone of the open pit in order to reduce the loss of output of haul trucks.
\end{abstract}

\section{Introduction}

It is known that rock haul trucks and coal haul trucks differ in body capacity with approximately the same carrying capacity, which is due to the fact that the density of coal is 1.5-2 times less than the overburden. For full use of loading capacity of haul truck, it is necessary to send haul trucks of corresponding purpose to the rock or coal faces accordingly. It is possible to send overburden haul trucks to loading coal, but it leads to underutilization of their carrying capacity. This measure can be resorted to when excavating small local volumes of coal. The problem is especially relevant due to the fact that in recent years, open-pit mining goes to greater depths, and mining and geological conditions of their

\footnotetext{
*Corresponding author: tma.geolog@kuzstu.ru
} 
operation are worsening due to the tectonic dislocations of seams, large underground water inflows, the general increase in the cost of the mined coal [1-24].

When coal and rock are excavated separately, long-term, constant requests for haul trucks by type of them are carried out, which is organizationally preferable.

To develop recommendations on this issue, let us consider the schedules of stripping and winning operations in the development of complex faces.

\section{Materials}

To determine the excavation time of the coal seam and the rock at different conditions of occurrence, we take the most common mining and geological conditions, as well as the brands of the most common equipment. Let's consider excavation of coal seam with thickness of 4, 6 and 8 meters with Liebherr R984C backhoe. To reduce the result to a single whole, we take the length of the excavated block to be 3 meters. The results of mining time calculation are presented in table 1. Legend of the table: $s_{t h}-$ coal seam thickness, $\mathrm{m} ; \varphi$ - dip angle, degrees; $V_{b l . o v}$ - volume of overburden in the extracting block, $\mathrm{m}^{3} ; t_{\text {bl.ov }}$ - time of overburden excavation in the block, shifts; $V_{\text {bl.coal }}$ - volume of coal in the extracting block, $\mathrm{m}^{3} ; t_{\text {bl.coal }}$ - time of coal excavation in the block, shifts.

Table 1. Joint mining of single coal seam and rock by Liebherr R984C excavator at the block length $l_{b l}=3 \mathrm{~m}$ and different bedding angles.

\begin{tabular}{|c|c|c|c|c|c|}
\hline$s_{t h}, \mathrm{~m}$ & $\varphi$, degrees & $V_{\text {bl.ov }}, \mathrm{m}^{3}$ & $t_{\text {bl.ov }}$, shifts & $V_{\text {bl.coal }, \mathrm{m}^{3}}$ & $t_{\text {bl.coal }}$, shifts \\
\hline \multirow{4}{*}{4} & 20 & 290 & 0.126 & 140 & 0.061 \\
\cline { 2 - 6 } & 30 & 266 & 0.116 & 96 & 0.042 \\
\cline { 2 - 6 } & 40 & 253 & 0.11 & 74.7 & 0.032 \\
\cline { 2 - 6 } & 50 & 244 & 0.106 & 62.6 & 0.027 \\
\cline { 2 - 6 } & 60 & 238 & 0.103 & 55.4 & 0.024 \\
\hline \multirow{4}{*}{6} & 20 & 290 & 0.126 & 210.5 & 0.091 \\
\cline { 2 - 6 } & 30 & 266 & 0.116 & 144 & 0.062 \\
\cline { 2 - 6 } & 40 & 253 & 0.11 & 112 & 0.0487 \\
\cline { 2 - 6 } & 50 & 244 & 0.106 & 04 & 0.0408 \\
\hline \multirow{4}{*}{8} & 60 & 238 & 0.103 & 83 & 0.036 \\
\cline { 2 - 6 } & 20 & 290 & 0.126 & 280.7 & 0.122 \\
\cline { 2 - 6 } & 30 & 266 & 0.116 & 192 & 0.083 \\
\cline { 2 - 6 } & 40 & 253 & 0.11 & 149 & 0.065 \\
\cline { 2 - 6 } & 50 & 244 & 0.106 & 125 & 0.054 \\
\hline
\end{tabular}

\section{Results}

The analysis of the obtained results and the drawn planograms shows the following.

When mining coal and rock together, it is necessary to alternate the feeding of rock and coal haul trucks because of the high rhythm of the type of work performed by the excavator, and the higher the angle of the bed, the more frequent will be the change of transport. This has the following disadvantages:

1) The need for constant availability of the right number of haul trucks of different purposes within the boundaries of the worked area.

2) The need for coal haulers is three times less than for rock haulers at high angles of coal bed occurrence, which essentially means the following: 3-4 coal haulers drive to 
excavator, they are loaded and take the coal to the coal stockpile, then either stand till the next call which leads to sharp decrease of their productivity, or drive to another work site which leads to unreasonable increase of fuel consumption.

3) The dispatcher of the motor depot must constantly monitor that the supply of haul trucks of the right type is not interrupted. If the supply is interrupted, then, for example, when loading coal into rock haulers there is an underutilization of hauling capacity by almost $50 \%$.

In order to eliminate these disadvantages, it is suggested to use one shift of 8 hours duration as a minimum operating time unit. Knowing the productivity of the backhoe, seam thickness and layer height, it is possible to determine the length of the excavation block, which will be worked by the excavator during one shift.

$$
l_{b l}=\frac{O_{\text {backhoe }} \cdot \sin \varphi}{h_{\text {layer }} \cdot t_{h}},
$$

where $O_{\text {backhoe }}$ - shift output of the backhoe, $\mathrm{m}^{3}$ per shift; $h_{\text {layer }}$ - height of the excavating layer, $\mathrm{m} ; t_{h}$ - horizontal thickness of the seam, $\mathrm{m}$.

For Liebherr R984C backhoe shift output calculating by formula

$$
O_{\text {backhoe }}=-2.9765 \cdot C^{2}+270.32 \cdot C-215.2 \text {, }
$$

where $C$ is a bucket capacity of the backhoe, $\mathrm{m}^{3}$.

Accordingly, the length of the block $l_{b l}$ is $60-100 \mathrm{~m}$. When mining a single seam, it is necessary to determine the time of trenching by rock and coal.

$$
\begin{gathered}
t_{\text {bl.ov }}=\frac{V_{\text {bl.ov }}}{O_{\text {backhoe }}}=\frac{h_{\text {layer }} \cdot l_{b l} \cdot\left(W_{\text {trench }}+0.5 h_{\text {layer }}\left(\cot \alpha_{s}+\cot \varphi\right)\right)}{O_{\text {backhoe }}}, \text { shifts; } \\
t_{\text {bl.coal }}=\frac{V_{\text {bl.coal }}}{O_{\text {backhoe }}}=\frac{h_{\text {layer }} \cdot l_{b l} \cdot t_{\text {seam }}}{O_{\text {backhoe }} \cdot \sin \varphi}, \text { shifts, }
\end{gathered}
$$

where $\alpha_{s}$ - angle of rock slope, degrees; $t_{\text {seam }}$ - normal thickness of coal seam, m; $W_{\text {trench }}-$ cutting trench width, $\mathrm{m}$.

Let's consider mining the trench and seam with one complex face. In this case, the length of the excavation block $l_{b l}=2-3 \mathrm{~m}$. Graph of stripping and winning works for the conditions: $t_{\text {seam }}=6 \mathrm{~m}, W_{\text {trench }}=18 \mathrm{~m}, h_{\text {layer }}=4 \mathrm{~m}, \varphi=20^{\circ} ; 40^{\circ} ; 60^{\circ}, \alpha_{s}=70^{\circ}$ is presented in Fig. 1.

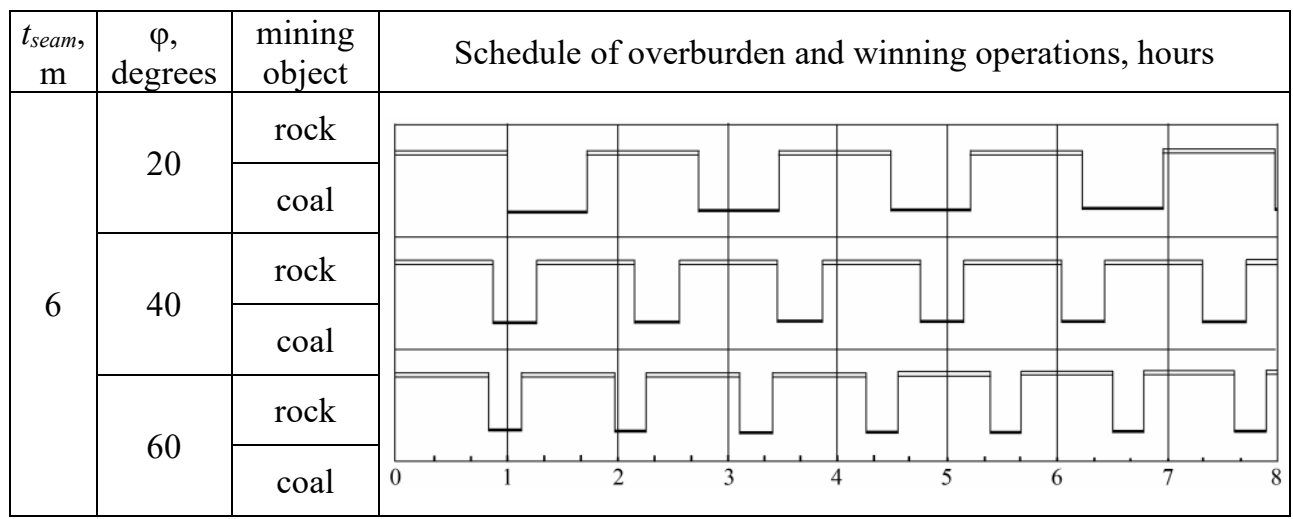

Fig. 1. Planogram of backhoe operation at joint excavation of cutting trench by layers and coal seam of different dip angle. 
When changing the thickness of the mined seam of $4,6,8 \mathrm{~m}$ and its dip angle of $20^{\circ}$, the graph will look as shown in Fig. 2.

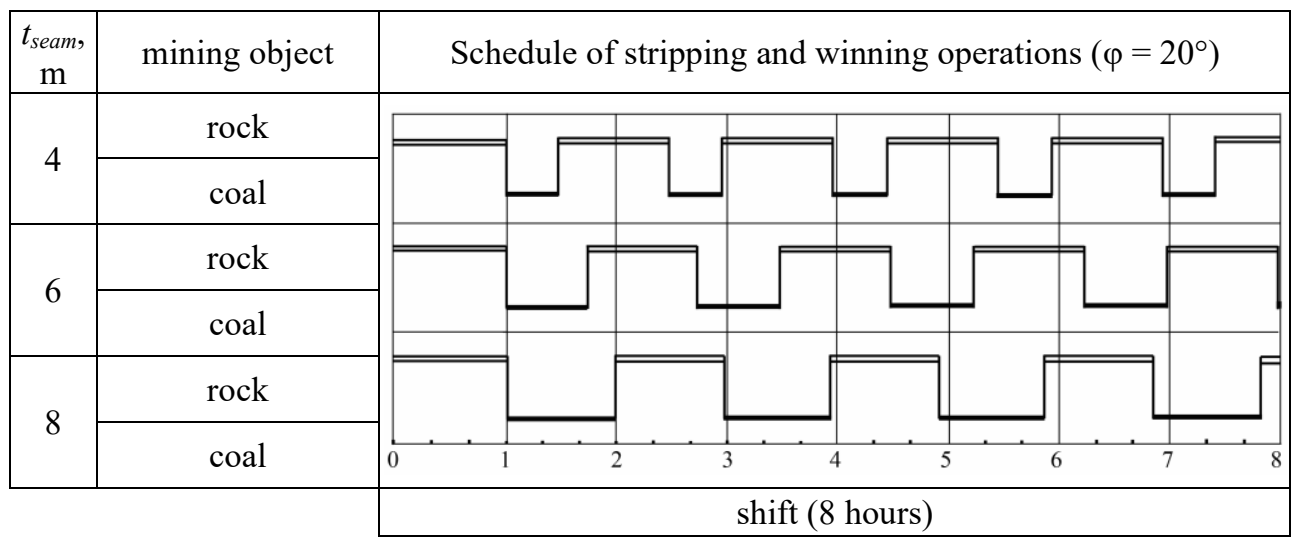

Fig. 2. Planogram of backhoe operation at joint excavation of cutting trench and coal seam of different thickness $(4,6,8 \mathrm{~m})$ with dip angle $20^{\circ}$.

Based on the condition of continuous operation with the direction of haul trucks of the same type (coal hauler) for a full working shift, it is necessary to determine the length of the excavation block. For excavators with different bucket capacity, the obtained results are presented in Table 2.

Table 2. Values of block lengths $\left(l_{b l}, \mathrm{~m}\right)$ when mining one seam.

\begin{tabular}{|c|c|c|c|c|c|c|c|c|c|c|c|}
\hline \multirow{2}{*}{ backhoe model } & \multirow{7}{*}{$\begin{array}{c}\text { shift } \\
\text { output, } \\
\mathrm{m}^{3} / \mathrm{shift}\end{array}$} & \multicolumn{6}{|c|}{$t_{\text {seam }}=2 \mathrm{~m}$} & \multicolumn{6}{|c|}{$t_{\text {seam }}=10 \mathrm{~m}$} \\
\cline { 3 - 13 } & 20 & 30 & 40 & 50 & 60 & 20 & 30 & 40 & 50 & 60 \\
\hline $\begin{array}{c}\text { Liebherr R984C } \\
\left(\mathrm{E}=5.2 \mathrm{~m}^{3}\right)\end{array}$ & 2300 & 98.3 & 143.7 & 184.8 & 220.2 & 249.0 & 19.7 & 28.7 & 37.0 & 44.0 & 49.8 \\
\hline $\begin{array}{c}\text { Liebherr R984C } \\
\left(\mathrm{C}=7.5 \mathrm{~m}^{3}\right)\end{array}$ & 3300 & 141.1 & 206.2 & 265.1 & 316.0 & 357.2 & 28.2 & 41.2 & 53.0 & 63.2 & 71.4 \\
\hline $\begin{array}{c}\text { Liebherr R994 } \\
\left(\mathrm{C}=10.3 \mathrm{~m}^{3}\right)\end{array}$ & 4250 & 181.7 & 265.6 & 341.5 & 407.0 & 460.1 & 36.3 & 53.1 & 68.3 & 81.4 & 92.0 \\
\hline
\end{tabular}

Analysis of the results shows that it is inexpedient to use a backhoe in all cases under consideration. For example, when using Liebherr R994 excavator $\left(C=10.3 \mathrm{~m}^{3}\right)$ for working out of low-thickness seams it appears that during one working shift its working face can move by $410-460 \mathrm{~m}$ that will create certain problems, for example, in constant preparation of the sites for haul trucks turning, road access cleaning, extension of lighting system and so on. On the contrary, excavators with a small capacity of a bucket, working out a powerful seam will be able to move its face only on 9-11 m that will increase coal pollution because of the great number of passages of haul trucks over it for drive up loading.

Therefore, it makes sense to limit the length of the block. And the length of the block and the seams dip angle are in direct correlation with each other.

As an example, we take Liebherr R984C excavator $\left(C=5.2 \mathrm{~m}^{3} ; O_{\text {backhoe }}=2300\right.$ $\mathrm{m}^{3} / \mathrm{shift}$ ) to further study the work mode.

Let's consider excavation of a complex face, including a cutting trench along the layer, two coal seams and parting. 
Initial data: $t_{\text {seam } 1}=t_{\text {seam } 2}=6 \mathrm{~m} ; t_{\text {parting }}=5 \mathrm{~m} ; W_{\text {trench }}=18 \mathrm{~m} ; h_{\text {layer }}=4 \mathrm{~m} ; \alpha_{s}=70^{\circ} ; \varphi=$ $20^{\circ} ; 30^{\circ} ; 40^{\circ} ; 50^{\circ} ; 60^{\circ} ; 70^{\circ} ; 80^{\circ} ; 90^{\circ}$; block length $l_{b l}=3 \mathrm{~m}$.

The final dependence of the mining time of the whole block and the time of mining only seam from its dip angle is shown in Fig. 3.

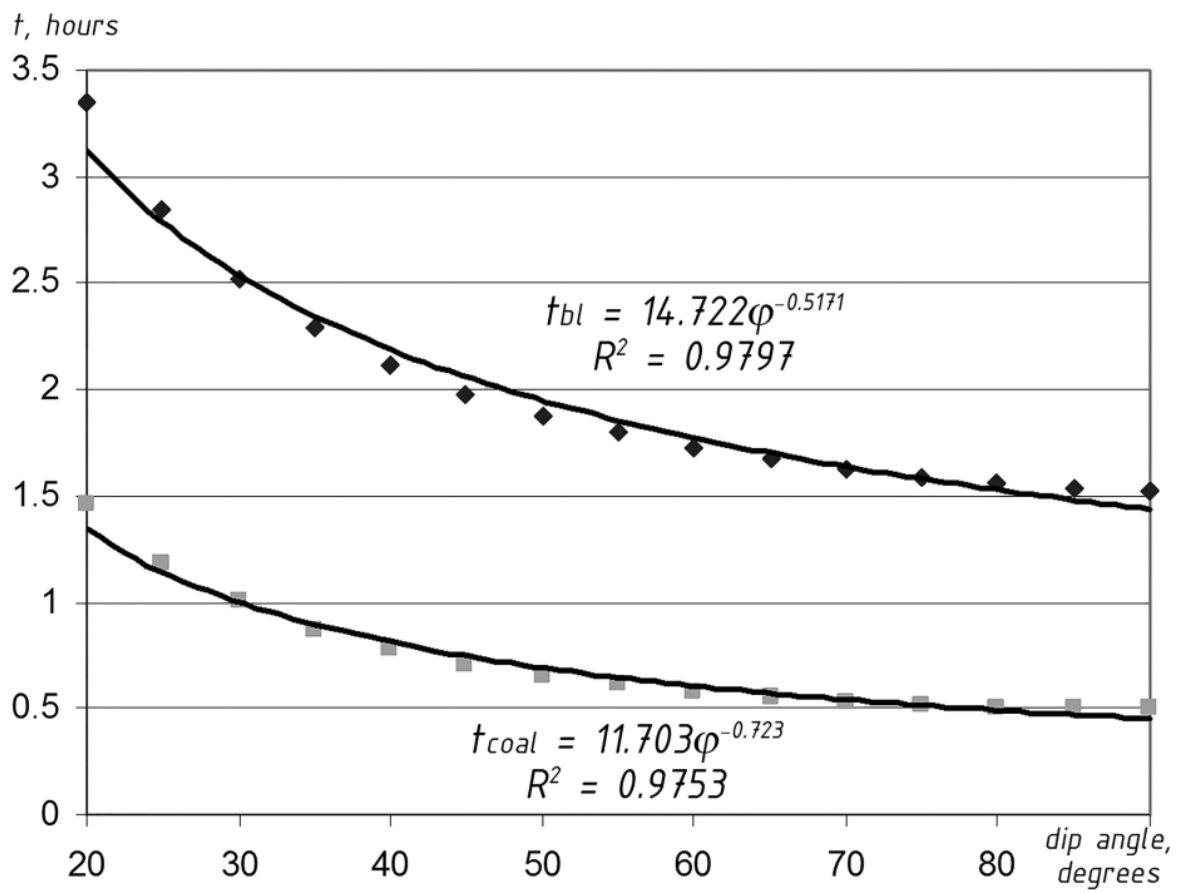

Fig. 3. Dependence of mining time of the whole block by Liebherr R984C backhoe and mining time of the coal seam only on its dip angle.

\section{Conclusions}

1. When using one working shift as a unit of time, it is necessary to take into account the capacity of the excavator bucket in relation to the thickness of the mined seams and partings.

2. With the known volumes of mining works, including excavation of the cutting trench, mining of seam (seams) and, if necessary, parting, setting one working shift as the minimum unit of time, it is possible to establish the required output of excavator and by the known relationship to choose the necessary model with the required capacity of the bucket.

3. When excavating complex rock-coal blocks with a continuous face $\left(l_{b l}=3 \mathrm{~m}\right)$ it is necessary to constantly monitor the supply of haul trucks of different types (rock haul trucks and coal haul trucks) for loading, which leads to the complexity of the organization of provision of hauling trucks for excavation machines.

\section{References}

1. T.N. Gvozdkova, M.A. Tyulenev, S.A. Zhironkin, V.A. Trifonov, Yu.M. Osipov, IOP Conference Series: Earth and Environmental Science, 50(1), 012010 (2017)

2. O. Litvin, M. Tyulenev, S. Zhironkin, S. Prokopenko, Acta Montanistica Slovaca, 22(2), 146 (2017) 
3. M. Tyulenev, S. Markov, M. Cehlar, S. Zhironkin, M. Gasanov, Acta Montanistica Slovaca, 23(4), 368 (2018)

4. A. Ključnikov, M. Civelek, V. Krajčík, I. Ondrejmišková, Acta Montanistica Slovaca, 25(2), 224 (2020)

5. T.A. Tyuleneva, Journal of Mining and Geotechnical Engineering, 1(12), 4 (2021)

6. A. Katsubin, S. Markov, A. Khoreshok, M. Tyulenev, E3S Web of Conf., 174, 01027 (2020)

7. A. Strelnikov, S. Markov, L. Rattmann, D. Weber, E3S Web of Conf., 41, 01003 (2018)

8. R.V. Klyuev, I.I. Bosikov, A.V. Mayer, O.A. Gavrina, Sustainable development of mountain territories, 12(2), 283 (2020)

9. D. Marasova, V. Zolotukhin, L. Ambrisko, International Multidisciplinary Scientific GeoConference Surveying Geology and Mining Ecology Management SGEM, 19(1.3), 57 (2019)

10. S. Markov, Ju. Janočko, M. Tyulenev, Ya.O. Litvin, E3S Web of Conf., 105, 01021 (2019)

11. T. Gvozdkova, S. Markov, N. Demirel, S. Anyona, E3S Web of Conf., 21, 01024 (2017)

12. A. V. Katsubin, A. A. Khoreshok, M. A. Tyulenev, S. O. Markov, Mining Inf. Anal. Bull., 2020(11), 27 (2020)

13. M. A. Tyulenev, S. O. Markov, M. A. Gasanov, S. A. Zhironkin, Geotech Geol Eng, 36(5), 2789 (2018)

14. S. Markov, M. Tyulenev, O. Litvin, E. Tyuleneva, E3S Web of Conf., 15, 01011 (2017)

15. V. Zolotukhin, E. Stepantsova, M. Kozyreva, A. Tarasenko, A. Stepantsov, E3S Web of Conferences, 15, 04014 (2017)

16. Yu. Lesin, V. Gogolin, E. Murko, S. Markov, Ju. Kretschmann, E3S Web of Conf., 41, 01039 (2018)

17. M. Tyulenev, A. Khoreshok, E. Garina, O. Litvin, Y. Litvin, E. Maliukhina, IOP Conference Series: Earth and Environmental Science, 50(1), 012035 (2017)

18. T. Gvozdkova, E. Kuznetsov, A. Rudakova, S. Markov, E3S Web of Conf., 15, 01008 (2017)

19. M. Tyulenev, S. Markov, E. Makridin, Yu. Lesin, V. Gogolin, E3S Web of Conf., 105, 02022 (2019)

20. P. Habek, W. Bialyand, G. Livenskaya, Acta Montanistica Slovaca, 24(1), 25 (2019)

21. S. Markov, V. Martyanov, E. Preis, A. Abay, E3S Web of Conf., 21, 01021 (2017)

22. V.A. Gogolin, Yu.V. Lesin, O.I. Litvin, Ya.O. Litvin, Journal of Mining and Geotechnical Engineering, 1(12), 69 (2021)

23. A. Belkov, V. Zolotukhin, N. Zolotukhina, N. Sedina, M. Kozyreva, E3S Web of Conferences, 134, 03005 (2019)

24. V. Murko, A. Zaostrovsky, E. Murko, M. Volkov, E3S Web of Conferences, 41, 01040 (2018) 